\title{
APRESENTAÇÃO DO PRIMEIRO NÚMERO DA REVISTA INGESTA
}

A história da alimentação, das bebidas e das drogas se constitui como um campo de circunscrição temática e conceitual de elementos distintos, mas sobrepostos. Os estudos sobre comida, bebidas alcoólicas e outras drogas se inscreveram nas tentativas de analisar o cerne da vida cotidiana e que é também a matéria-prima da economia, ou seja, as práticas que podemos chamar de ingestões.

Ingerir é assimilar no corpo produtos externos que se consubstanciam na própria carne constituindo assim o seu alimento reprodutor, mas também reguladores psicofisiológicos que desde as épocas mais arcaicas foram encontrados com a fermentação de matérias orgânicas e a riqueza psicoativa da flora.

Por isso, denominamos essa revista que apresenta agora o seu primeiro número de Ingesta, ou seja, ingestões que esperamos sejam também digestivas e nutritivas. O termo latino digerere significa não só digerir no estômago, mas também "colocar em ordem". Por isso, a expressão Digesto passou a designar a maior compilação jurídica do direito romano, mas também a ideia de uma leitura enciclopédica. Em inglês, também passou a significar um resumo, uma leitura já "digerida" e, portanto, facilmente assimilável, como era o nome da famosa revista estadunidense Reader's Digest.

No nosso caso, esperamos poder trazer mastigações mais analíticas, sabores inspiradores e uma digestão intelectual mais lenta e reflexiva. Não será, portanto, um Digesto, mas uma Ingesta.

Esperamos conseguir nos aprofundar mais na manducação das ideias e na digestão do debate sobre a comida, a bebida e as substâncias psicoativas e as formas dos seus usos, em perspectiva histórica.

Mais do que apenas os produtos, é da sua regulação que se trata, de sua posição social, econômica, cultural, política, religiosa, estética. O que se ingere é gerido e propomos aqui investigar as gestões das ingestões. As primeiras carências humanas a serem sempre geridas são as da sede e da fome.

Cerir, ingerir e digerir: três conceitos associados ao ordenamento da relação entre os corpos e os seus ambientes, provedores de manutenção e restauração. Esse ordenamento não é meramente nutricional, mas fornece também uma das partes mais importantes do repertório simbólico das mais variadas culturas humanas.

Esta linha de pesquisa se iniciou no âmbito do Departamento de História da USP, onde surgiu o LEHDA (Laboratório de Estudos Históricos das Drogas e da Alimentação). Fazem parte dele os pósgraduandos e também alunos de iniciação científica na graduação. No seu site - lehda.fflch.usp.br - encontram-se acessíveis todas as teses de doutorado e dissertações de mestrado já defendidas pelos seus integrantes, assim como artigos, referência dos livros publicados e participação em eventos dos seus integrantes. 
Em 1999, em artigo do professor Ulpiano T. Bezerra de Meneses com minha colaboração', constatamos que a historiografia brasileira da alimentação ainda era pobre, e que existia mais como um apêndice, tendo sido a História econômica, a História da vida cotidiana e a Antropologia que abrigaram uma produção mais continuada e sistemática. Passadas duas décadas e podemos constatar uma proliferação e também sedimentação desses estudos.

Sentindo a necessidade de ter um veículo que divulgasse mais os trabalhos nesse campo do conhecimento, permitindo assim o aprofundamento do debate, estamos lançando agora o primeiro número da nossa revista Ingesta.

São dezesseis artigos inéditos, de pesquisadores e professores do Brasil e uma da Argentina, que tratam do amplo espectro de temas que se enfeixam nas práticas de ingestão.

Sobre alimentação temos dez artigos sobre os temas a seguir: a ciência da nutrição e os modelos alimentares para a América Latina nas instituições e políticas de assistência alimentar; a pesquisadora Marion Nestle e sua análise dos lobbies alimentares; as tradições culinárias de Minas Gerais do Festival Igarapé Bem Temperado; a proposta de farinata da prefeitura de São Paulo e os riscos alimentares; o perfil das confeitarias do Rio de Janeiro na segunda metade do século XIX, a partir de um levantamento de periódicos; os relatos sobre comida de Ver Huell, um holandês que passou quase três anos na Bahia do começo do XIX; a curadoria da exposição no Museu Republicano de Itu de cardápios e banquetes na $1^{\text {a }}$ República; os paradigmas alimentares das narrativas bíblicas, o maná e o banquete; a colonização das dietas indígenas por sistemas de produção de carne, enfocando o caso do povo Karitiana, de Rondônia; as dietas e regimes no discurso médico em enciclopédias publicadas no Brasil entre 1958 e 1973.

A respeito de bebidas, trazemos um artigo sobre a bebida manicuera feita de mandioca e o seu uso na sociabilidade de finados no Pará; e outro sobre usos terapêuticos da ayahuasca num contexto de intermedicalidade numa comunidade do Santo Daime no sul de Minas em que convivem diferentes sistemas médicos.

Em relação às drogas, há quatro artigos sobre: a construção social do problema da droga na Argentina do início do século XX até hoje; a proposta original de Maxwell Jones das comunidades terapêuticas e sua realidade contemporânea no Brasil; a hipótese de um complexo das drogas na América indígena e seu papel nas formações estatais indígenas; e um estudo comparativo entre Estados Unidos e Brasil sobre o manejo da dor e a compaixão canábica na perspectiva de uma "farmacopeia política".

Temos, portanto, um cardápio amplo de temas que tratam de muitos aspectos sob olhares ancorados em pesquisas monográficas muito ricas que investigam manifestações peculiares de nossa relação com o que se come ou se bebe, como isso se faz, com quais significados e com que repercussões.

Quero aproveitar o ensejo do lançamento desta revista para homenagearmos neste número inaugural dois historiadores fundadores no Brasil do campo de estudos históricos da alimentação e 
das bebidas, precocemente falecidos, que são Carlos Roberto Antunes dos Santos (1945-2013) e João Azevedo Fernandes (1963-2014).

Na Universidade Federal do Paraná, onde também foi reitor, Antunes dos Santos aglutinou um profícuo núcleo acadêmico de história da alimentação, orientou alunos, promoveu congressos e editou revistas sobre esse tema. Seu livro A história da a limentação no Paraná (1995) é um dos melhores exemplos de um trabal ho profundo sobre uma região, com a sua história agrícola e comercial sendo analisada sob o prisma do complexo alimentar.

João Azevedo Fernandes foi o pioneiro no estudo das bebidas alcoólicas no Brasil. Debruçouse sobre os dois primeiros séculos da colonização para buscar compreender o choque dos regimes etílicos existentes entre os nativos e aquele advindo dos portugueses e outros europeus. $\mathrm{Na}$ Universidade Federal do Rio Grande do Norte desenvolveu sua docência e pesquisa aprofundando o estudo da história das bebidas, sobre a qual publicou Selvagens bebedeiras. Álcool e contatos culturais no Brasil Colonial. Séculos XVI-XVII (2011).

Esperamos poder dar continuidade ao esforço acadêmico desempenhado por estes dois pioneiros e abrir mais um espaço de diálogo e debate teórico sobre as múltiplas dimensões das ingestões humanas em escala global, mas, especialmente, naquilo que é específico do nosso país.

Queeste e os próximos números da revista Ingesta possam continuar a estimular esse percurso.

\author{
Henrique Carneiro \\ Coordenador do Laboratório de Estudos Históricos das Drogas e da Alimentação \\ (LEHDA-USP)
}

